\title{
Depositional conditions of the coal-bearing Hirka Formation beneath Late Miocene explosive volcanic products in NW central Anatolia, Turkey
}

\author{
MEHMET ŞENER \\ Department of Geology, Niğde University, 51200, Nĭ̆ge, Turkey. \\ e-mail: msener@nigde.edu.tr
}

This work focuses on the relationship between the coal deposition and explosive volcanism of the Miocene basin, NW central Anatolia, Turkey. The coal-bearing Hirka Formation was deposited over the Galatian Andesitic Complex and/or massive lagoonal environments during the Miocene. The investigated lignite is a high ash (from 32 to $58 \%$ ) and sulphur (from 1.43 to $3.03 \%$ ) lignite which is petrographically characterised by a high humunite content. The mineral matter of the studied lignite samples is made up of mainly clay minerals (illite-smectite and kaolinite), plagioclase and quartz in Bolu coal field, clay minerals (illite-smectite, smectite and illite), quartz, calcite, plagioclase and gypsum in Seben coal field, quartz, K-feldspar, plagioclase and clay minerals (kaolinite and illite) in Kıbrıscık, and dolomite, quartz, clinoptilolite, opal CT and gypsum in Çamlıdere coal field. The differences in these four types of lignite with specific mineralogical patterns may be due to the explosive volcanic events and depositional conditions which changed from one coal field to the others. There is a zonation from SW to SE in the studied area for zeolites such as Opal CT+smectite-clinoptilolite-analcime-K-feldspar. Carbonate minerals are commonly calcite in Seben and Kibriscik coal fields. In Bolu, coal samples are devoid of calcite and dolomite. These analyses show that there is an increase in the amount of $\mathrm{Mg}$ and a decrease in the amount of $\mathrm{Na}$ from the northwestern part to the southern part in the study area.

\section{Introduction}

During the period Neogene to Quaternary, several lacustrine basins developed in Turkey. The Neogene basins were filled by clayey, carbonaceous and sandy sediments, and also by explosive products of contemporaneous K-rich calc-alkaline volcanism with various degrees of crustal contamination (Yılmaz 1989; Güleç 1991; İnci 1991; Gündoğdu et al 1996). These basins are generally characterised by volcanic-sedimentary successions. Places including the study area are characterised by important fossil-fuel and industrial-mineral resources such as lignite, oil shale, clays, borates and zeolites (Şener et al 1995; Gündoğdu et al 1996; Şener and Gündoğdu 1996).
The study area is located between Bolu and Ankara in NW central Anatolia (figure 1a). A large part of the studied Neogene basin is covered by Upper Miocene pyroclastic rocks. The coal-bearing Hirka Formation was first named by Aziz (1976) in the Beypazarı basin, situated approximately $100 \mathrm{~km}$ northwest of Ankara in central Anatolia. This formation is understood to have been deposited on the Galatian andesitic complex (or massif) under stable lacustrine conditions. There are four coalfields in the study area: the Bolu coal field, the Seben coal field, the Kibriscik coal field and the Çamlıdere coal field (figure 1b).

The area has been studied from time to time with respect to geological, stratigraphical and volcanological characteristics. The first geological

Keywords. Coal; oil shale; zeolite; clay minerals; Galatian andesite complex; Turkey. 


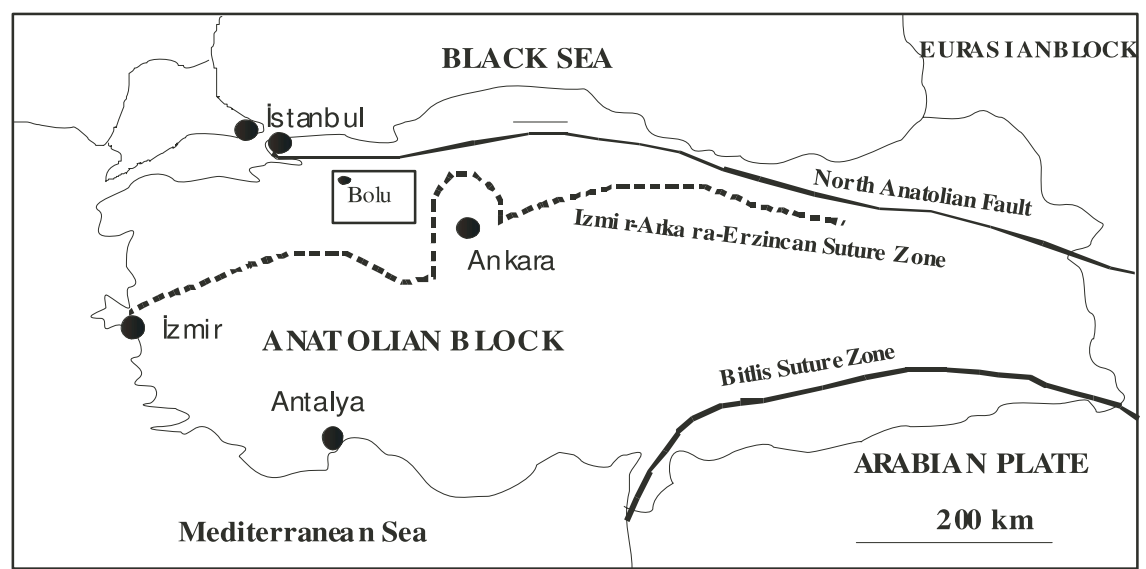

(a)

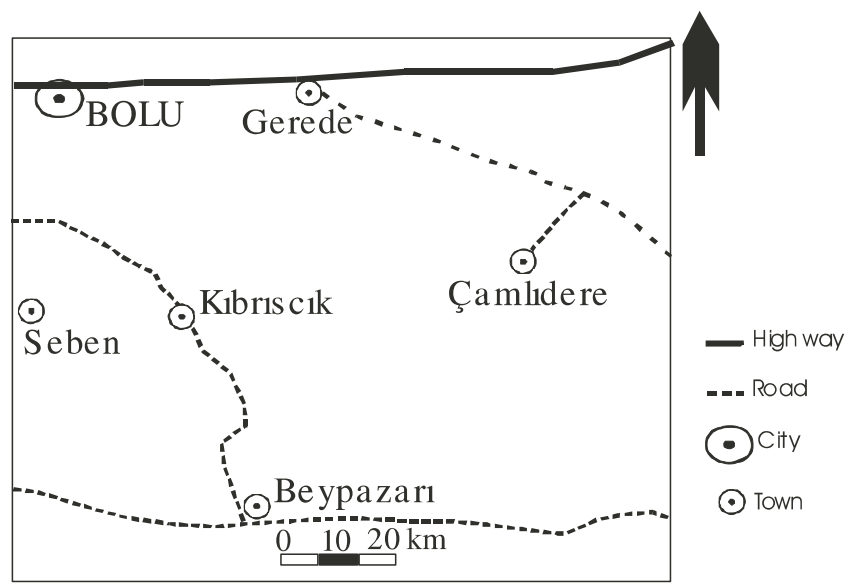

(b)

Figure 1. Location map of (a) study area and (b) coal seams.

reports of the area were made by Milch (1903); Chaput (1931); Blumenthal (1941); and Türkecan et al (1991).

In the present study, I have carried out detailed geological, petrographic and geochemical studies of a large number of samples from all the coal seams measuring $\geq 1 \mathrm{~m}$ in thickness. The main objective of this study is to focus on the petrographic composition of coals and other rocks formed on the andesitic complex under stable lacustrine conditions. Further, variations in petrographic composition of the coals and other rocks have been used to reconstruct the palaeodepositional conditions for the coal deposits.

\section{Geological setting and tectonic evolution}

The coal-bearing strata belong to the Hirka Formation of the Köroğlu Group (table 1). The oldest rocks exposed in the vicinity (Paleozoic) are the Sekli Metamorphics, which comprise the basement to the Cretaceous sediments. The CretaceousEocene sedimentary sequences of the region are exposed along the south-eastern edge of the Sekli Metamorphics. The lowermost unit of this depositional period is the Keltepe Formation (200 m thick), which rests unconformably on the Sekli Metamorphics and consists of hard, thick-bedded limestone - dolomite of variable colours (grey, white and light yellow) followed by thin beds of softer marl at top.

The Keltepe Formation is overlain conformably by the Gölcük Formation of the Aladağçay Group (150-180 $\mathrm{m}$ thick). This formation comprises sandstone, claystone, mudstone, marl and limestone containing Senonian-Maastrichtian foraminifera. The top of the Seben Formation, which consists of marl containing Senonian-Maastrichtian molluscs, referegents the Cretaceous-Tertiary boundary.

The older Tertiary belongs to the Cuisian Emenler Formation that consists of marl (50-75 m thick). The Emenler Formation unconformably overlies all of the older formations (the Gölcük and others). The Taşlık Formation conformably overlies 
Table 1. Geological succession of coalfields of investigated area (after Taka et al 2001).

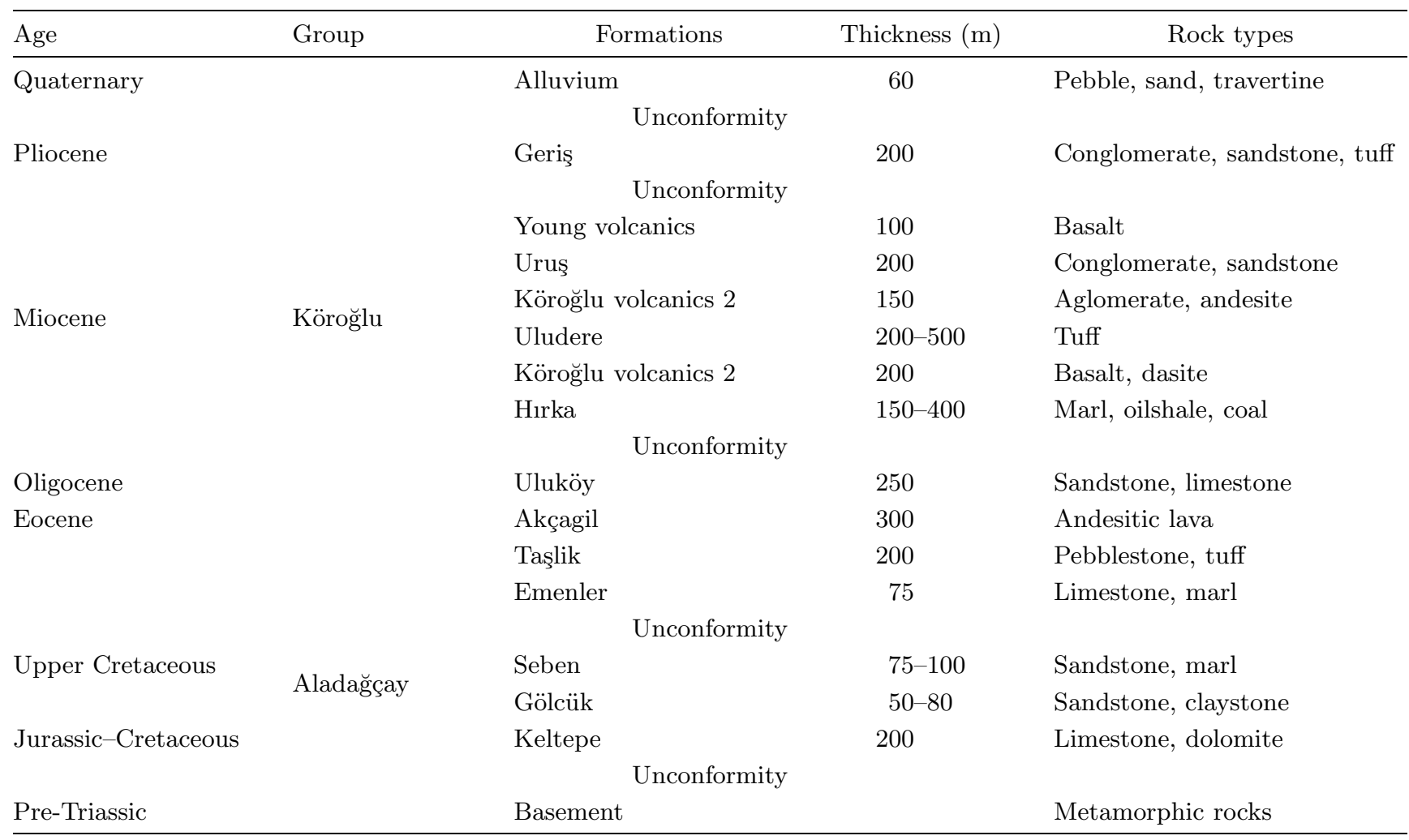

the Emenler Formation and comprises pebblestone, sandstone, mudstone, tuff and limestone (200 $\mathrm{m}$ thick). Nummulitic fauna indicate that the Taşlık Formation is lower-middle Eocene in age. Eocene-Oligocene aged Akçagil Formation consists of interbedded agglomerate, tuff, andesitic lava, sandstone, siltstone, claystone and limestone. The Akçagil Formation is conformably overlain by the Uluköy Formation. The thickness of Uluköy Formation has been found to be quite variable by various investigators; it ranges from a minimum thickness of $250 \mathrm{~m}$ up to $2000 \mathrm{~m}$ in the Beypazarı basin (Aziz 1976). Fauna and stratigraphic position indicate that the Uluköy formation is of Oligocene age.

The Köroğlu Group is made up of six formations, based on lithological distinctions and fossil content: the Hirka Formation, the Köroğlu Volcanities 1, the Uludere Pyroclastics, the Köroğlu Volcanities 2, the Uruş Formation, and the Young Volcanics (table 1). Miocene sedimentation began with the deposition of the interfingering Hirka Formation and Köroğlu Volcanities 1, Uludere Pyroclastics, which unconformably overlie the Uluköy Formation. The Hirka Formation is coal-bearing and in fact, all of the coal research in the study area has been focused on this unit. The Early Miocene Hirka Formation is $150-400 \mathrm{~m}$ thick and comprises of marl, oil shale and coal seams; it interfingers vertically and laterally with the Uludere Pyroclastics, comprising thick-layered tuff and Köroğlu Volcanities 1, comprising basaltic-dasitic lava. However, generally speaking, the coal-bearing strata of the Hirka Formation lie beneath the Uludere Pyroclastics. Petrographic studies of the tuffs reveal that they are composed of plagioclase, quartz and K-feldspar crystal fragments and lithic fragments in an argillized volcanic-glass matrix. The tuffs are products of extensive volcanic activity, which distributed large amounts of ash over the Kıbriscik and Seben coal fields, and occur as continuous bands extending $100 \mathrm{~km}$ from Çamlidere to the Bolu coal fields (table 1). According to Taka et al (2001), each tuff represents several cycles of eruptive activity and deposition in lacustrine and terrestrial environments by a combination of pyroclastic fall, flow and surge. Also present are tuffites which formed in lakes by transportation of original ash deposits. The Uruş Formation, comprising conglomerate and sandstone, conformably overlies the Hirka, Köroğlu Volcanites 1; Uludere Formations and Köroğlu Volcanites 2 consist of agglomerate and andesite. The thickness of this unit is $200 \mathrm{~m}$ and its age is Upper Miocene.

Upper Miocene-Pliocene aged Young volcanics consists of basaltic lava. The Geriş Formation is the youngest unit in the area; it is Pliocene in age and comprises of conglomerate, sandstone and tuff; 

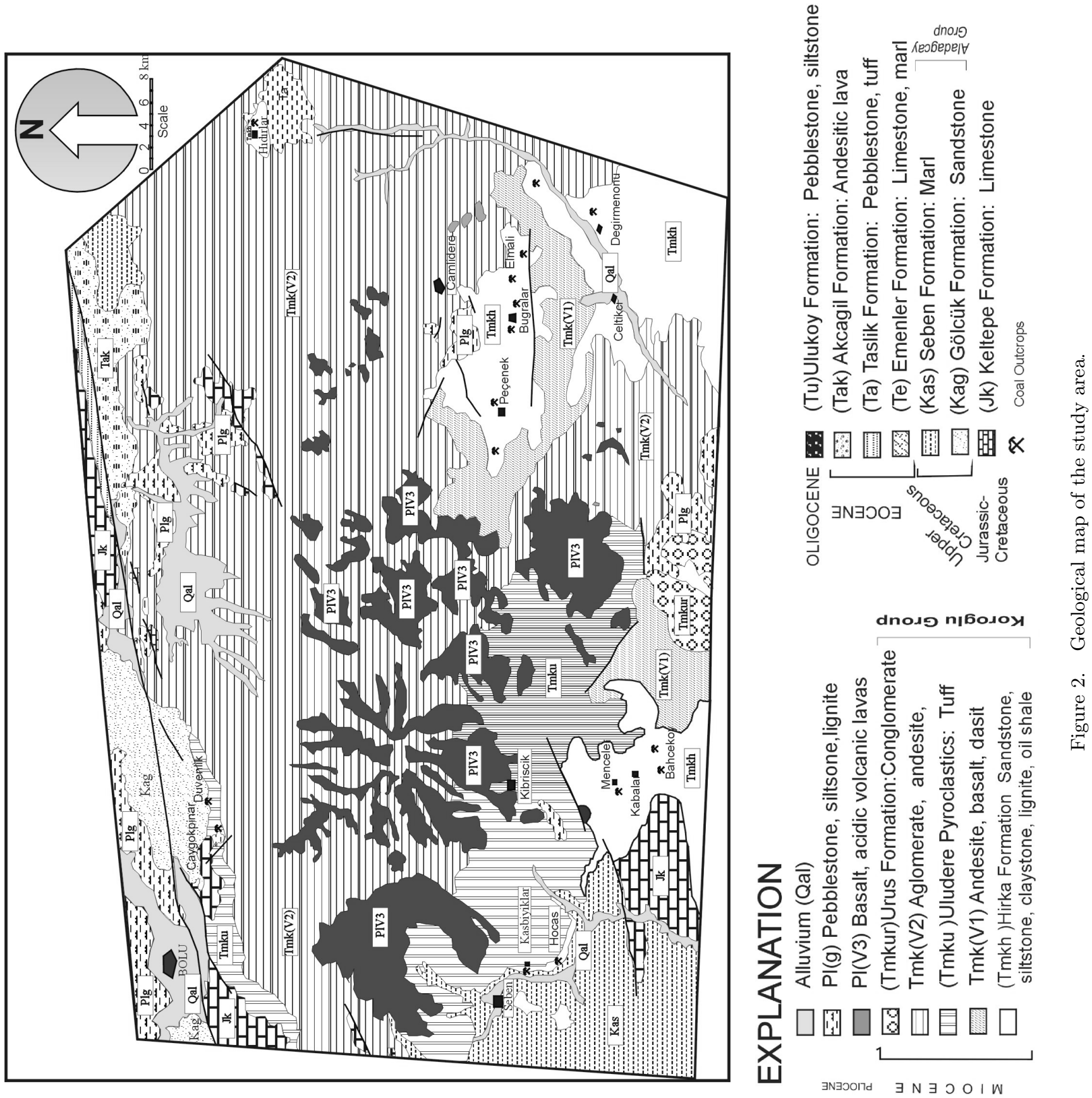


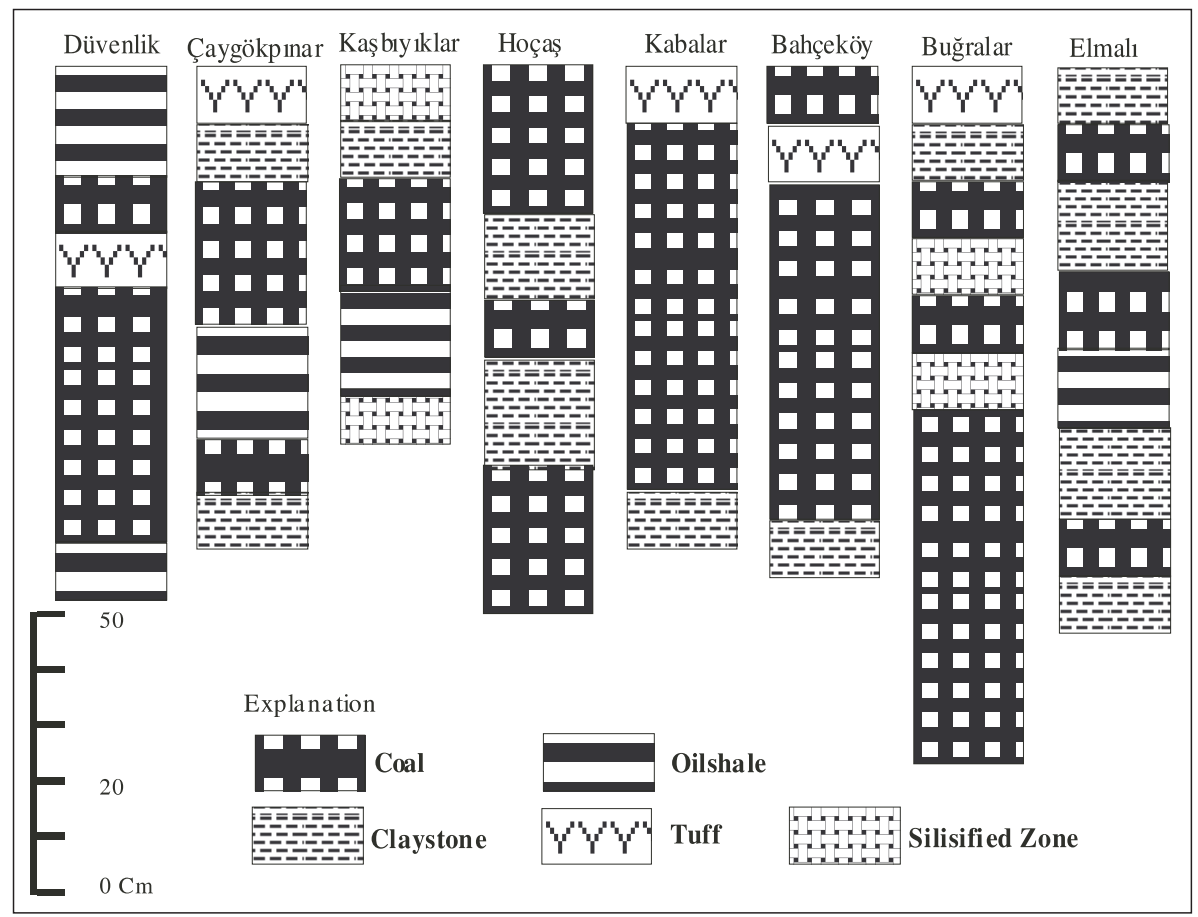

Figure 3. Measured stratigraphic section of coal seams.

$200 \mathrm{~m}$ thick, this formation unconformably overlies all other lithostratigraphic units.

The tectonic evolution of Turkey since the early Miocene has been controlled by two collisions along the İzmir-Ankara-Erzincan and Bitlis sutures (figure 1a). N-S intracontinental convergence associated with the Palaeocene-Eocene İzmir-AnkaraErzincan suture continued until the late Miocene (Şengör and Yılmaz 1981). On the other hand, the Middle Miocene Arabia-Eurasia collision, along the Bitlis suture in south-eastern Turkey (Sengör and Yllmaz 1981), accepted as the beginning of the neotectonic period in Turkey (Şengör 1980), has generated a $\mathrm{N}-\mathrm{S}$ extensional regime in western Turkey since the late Miocene (Şengör et al 1985).

During this tectonic evolution, a large number of northeast- and northwest-trending basins have developed within the İmir-Ankara suture zone, which is occupied by ophiolitic, metamorphic and sedimentary rocks of Permian to Eocene age. In the basin, the main tectonic structures affecting the Miocene units are oblique faults and roll-over type folds, which are generally parallel to the trends of the basins and the İzmir-Ankara suture.

\section{Mode of occurrence of the miocene coal seams}

\subsection{Coal fields of Bolu}

The coal fields of Bolu are the Düvenlik and Çaygökpınar fields. There are two coal seams in these fields. The upper seam is about 0.10 $0.25 \mathrm{~m}$ thick while the lower seam is about 0.10 $0.45 \mathrm{~m}$ thick (figures 2 and 3 ).

\subsection{Coal fields of Seben}

The major coal fields of Seben are the Hoçaş and Kaşbiyıklar. The coal deposit is situated in an approximately $4 \mathrm{~km}$-long, E-W-trending horizon. There are three coal seams in the Hoças coal field. The upper seam is about $0.50 \mathrm{~m}$ thick, the middle seam is $0.25 \mathrm{~cm}$ thick, while the lower seam is $0.50 \mathrm{~m}$ thick. All of these seams are still being mined actively. A $0.10 \mathrm{~m}$-thick claystone bed is present between the middle and lower seams. There are two outcrops in the Kaşbiyılklar coal field: one of them has one seam $0.20 \mathrm{~m}$ thick, while the other has three coal seams that range from 0.10 to $0.25 \mathrm{~m}$ in thickness. There is a $0.20 \mathrm{~m}$-thick tuff layer between the middle and upper seams in the Kaşbiyıklar coal field (figures 2 and 3).

\subsection{Coal fields of Kıbrıscık}

The coal fields of Kibriscik are the Kabalar and Bahçeköy fields. The Kabalar coal field is located north of Beypazarı at a distance of about $45 \mathrm{~km}$ on the Beypazarı-Ankara road. There is one $0.80 \mathrm{~m}$ thick coal seam in the Kabalar field, while the Bahçeköy coal field has two coal seams. The lower seam is $0.80 \mathrm{~m}$ thick while the upper seam is $0.10 \mathrm{~m}$ thick; the two seams are separated by thick tuff and limestone interlayers (figures 2 and 3 ). 
Table 2. Results of proximate and ultimate analyses.

\begin{tabular}{lrrrr}
\hline & Bolu & Seben & Kibrıscık & Çamlıdere \\
\hline Moisture \% & 30 & 32 & 25 & 29 \\
Ash \% & 32 & 36 & 38 & 37 \\
Volatile matter \% & 14 & 10 & 9 & 5 \\
Fixed carbon \% & 24 & 22 & 18 & 19 \\
Nett calorific value kcal/kg & 4376 & 3460 & 1185 & 3763 \\
Gross calorific value kcal/kg & 4875 & 3852 & 1362 & 3995 \\
Combustible S \% & 1.46 & 0.01 & 1.64 & 2.01 \\
Sulphur in ash \% & 0.64 & 1.42 & 0.06 & 1.02 \\
Total S \% & 2.10 & 1.43 & 1.70 & 3.03 \\
\% Rmax & 0.61 & 0.36 & 0.34 & 0.37 \\
\hline
\end{tabular}

\subsection{Coal fields of Çamludere}

The minor coalfields of Çamlıdere are the Buğralar and Elmall fields. There are three coal seams in the Bugralar coal field. The upper seam is about $0.15 \mathrm{~m}$ thick and the middle seam is $0.10 \mathrm{~m}$ thick, while the lower seam is about $0.65 \mathrm{~m}$ thick. The Elmalı coal field has three coal seams whose thicknesses vary from $0.05 \mathrm{~m}$ to $0.20 \mathrm{~m}$ (figures 2 and 3 ).

\section{Methods of study}

Pillar coal samples were taken at a series of outcrops and in galleries; these samples reflected the exposed thickness of the seam at the sampling point (figures 2 and 3). Proximate and ultimate analyses as well as petrographic analyses were carried out. Additionally HI, OI, TOC and mineralogical contents were determined.

For coal-petrographic analyses, samples were crushed to less than $1 \mathrm{~mm}$. Maceral analyses were conducted on polished pellets using $32 \times$ oilimmersion objectives. Fluorescent light was also used to identify the liptinite macerals. Petrographic analyses were based on point-counting methods; for maceral analyses, 250-300 points were counted, whereas 100 readings were taken for reflectance measurements. Maximum reflectance measurements on eu-ulminites A and B were carried out using a reflected-light microscope (Leitz MPV SP) with a $3 \times$ oil-immersion objective and sapphire standard for calibration $(0.551 \% \mathrm{R})$.

The contents of total organic carbon (TOC) and total sulphur (TS) were carried out on samples with a LECO-CS analyser; carbonate was removed using dilute hydrochloric acid. Calorific values were determined using calorimeters after BIN 51.900. The mineralogical compositions of 58 samples were determined via XRD analysis.

\section{Results and discussion}

\subsection{Proximate and ultimate analyses}

Table 2 shows the results of the proximate and ultimate analyses of composite profile samples from the four coal fields in the study area. Ash contents range from 32 to $58 \%$. The Kibriscik sample is characterised by the highest ash content and the lowest calorific value, whereas the Bolu sample has the lowest ash content. The higher calorific values range from 1362 to $4857 \mathrm{kcal} / \mathrm{kg}$.

Total sulphur contents range from 1.43 to $3.03 \%$. The Camlıdere lignite has the highest $\mathrm{S}$ total content $(3.03 \%)$, whereas the Bolu and Seben coal fields have intermediate levels $(1.70-2.10 \%)$, and the Seben coal fields has lower S total (1.43\%). The combustible S content of the Kibriscik sample is higher than the samples from the other coal fields, and the pyritic S contents of the Seben and Çamlidere coal-field samples are higher than those from other fields. These results indicate that organic sulphur contents in the study area decreased from SW to $\mathrm{S}$ where tuff deposition was greater.

\subsection{Rank}

Volatile-matter contents and vitrinite reflectance have been used as parameters for determining the approximate rank of the coals. The volatile-matter contents (d.a.f. basis) of samples from the studied coal fields range from 24 to $44 \%$ (table 2). The vitrinite reflectance (Ro mean) of samples from the studied fields ranges from 0.25 to 0.83 (figure 4).

The Bolu coal samples have volatile-matter contents and Rm\% higher than the samples from the other coal fields. The volatile-matter contents (24-44\%) and Ro\% mean values (0.350.61) suggest that these coals range in rank from 


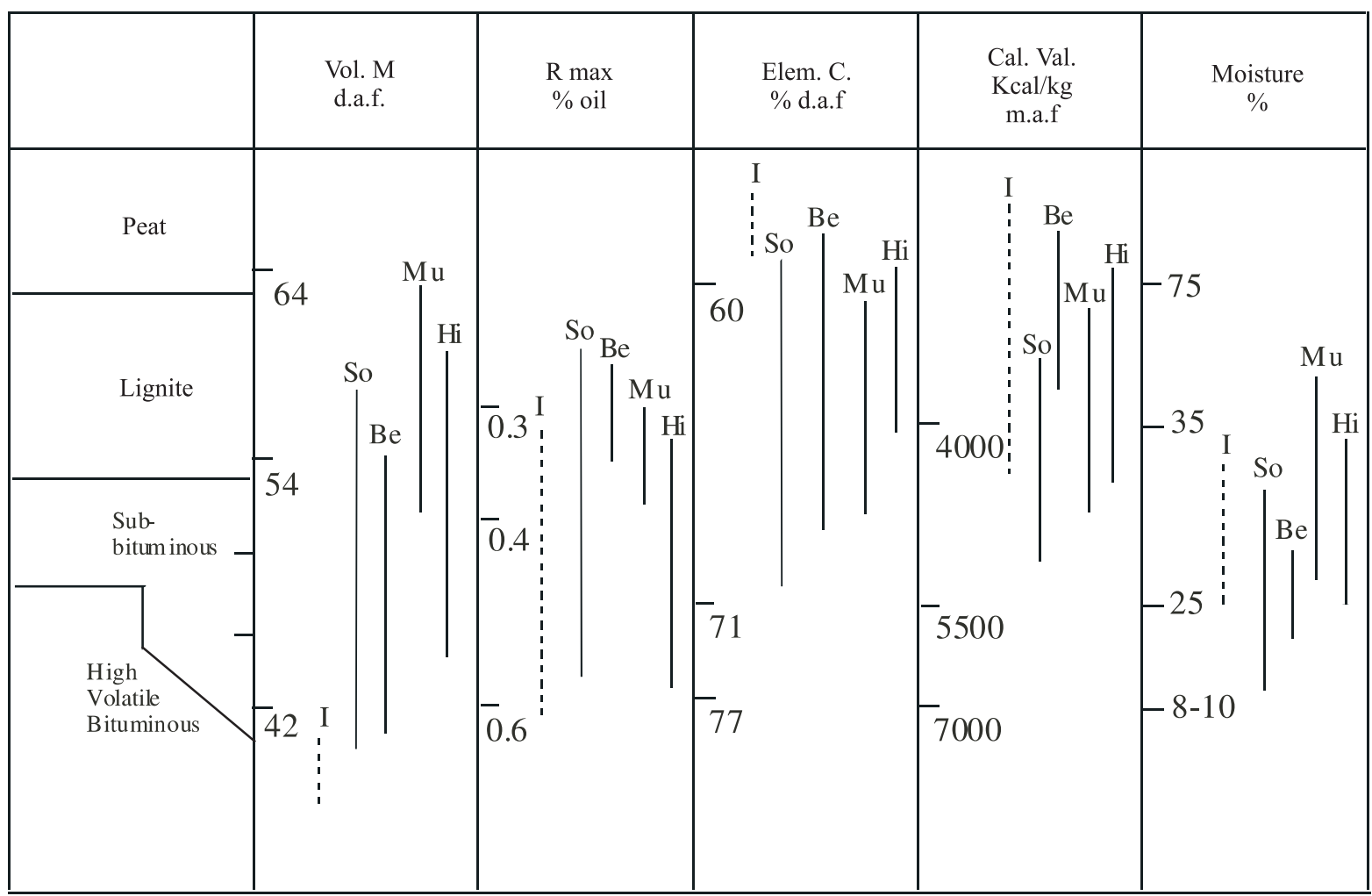

Figure 4. Coal-rank classification based on ASTM D-388-1984 and Teichmuller and Teichmuller (1982). Maf: moist ash-free basis; daf: dry ash-free basis. M: Muğla basin samples (from Querol et al 1999); H: Himmetoğlu samples (from Şener and Gündoğdu 1996); Be: Beypazarı samples (from Whateley and Tuncalı 1995); So: Soma basin samples (from Sengüler et al 2000); I: studied samples.

Table 3. Mean percentages of macerals for coal samples from the investigated area.

\begin{tabular}{|c|c|c|c|c|c|c|}
\hline \multicolumn{3}{|c|}{ Macerals } & \multirow{2}{*}{$\frac{\text { Bolu }}{3}$} & \multirow{2}{*}{$\frac{\text { Seben }}{2}$} & \multirow{2}{*}{$\frac{\text { Kıbriscık }}{3}$} & \multirow{2}{*}{$\frac{\text { Çamlıdere }}{2}$} \\
\hline \multirow{7}{*}{ Humunite } & \multirow{3}{*}{ ( Humotelinite } & Textinite & & & & \\
\hline & & Texto-ulmunite & 6 & 4 & 3 & 5 \\
\hline & & Eu-ulmunite & 8 & 5 & 2 & 4 \\
\hline & \multirow{2}{*}{ Humodetrinite } & Attrinite & 2 & 3 & 0 & 4 \\
\hline & & Densinite & 4 & 5 & 4 & 4 \\
\hline & \multirow{2}{*}{ Humocolinite } & Gelinite & 35 & 34 & 8 & 32 \\
\hline & & Corpohumunite & 0 & 1 & 0 & 1 \\
\hline \multirow{3}{*}{ Total humunite } & & & 58 & 54 & 20 & 52 \\
\hline & (Sporinite & & 3 & 3 & 2 & 2 \\
\hline & Alginite & & 0 & 1 & 0 & 0 \\
\hline \multirow[t]{3}{*}{ Liptinite } & Resinite & & 0 & 0 & 0 & 1 \\
\hline & Cutinite & & 2 & 1 & 2 & 2 \\
\hline & Liptodetrinite & & 2 & 1 & 1 & 1 \\
\hline \multirow[t]{3}{*}{ Total liptinite } & & & 7 & 6 & 5 & 6 \\
\hline & (Fusunite & & 0 & 0 & 1 & 0 \\
\hline & Macrinite & & 2 & 1 & 2 & 1 \\
\hline \multirow[t]{2}{*}{ Inertinite } & Sclerotinite & & 0 & 0 & 0 & 0 \\
\hline & Liptodetrinite & & 1 & 1 & 1 & 1 \\
\hline \multicolumn{7}{|l|}{ Total inertinite } \\
\hline \multicolumn{2}{|c|}{ Pyrite } & 8 & 5 & 6 & 5 & \\
\hline \multicolumn{2}{|c|}{ Clay minerals and silica } & 24 & 33 & 55 & 35 & \\
\hline
\end{tabular}




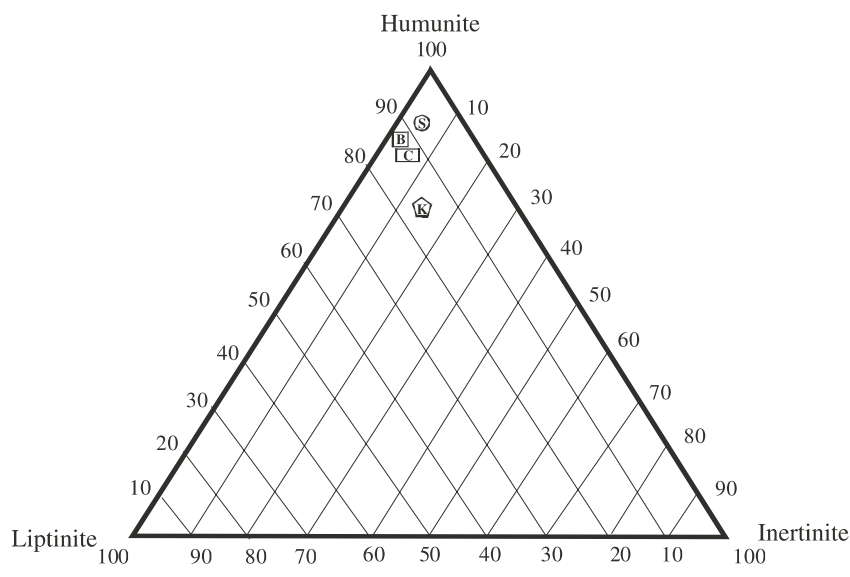

Figure 5. Ternary diagram showing the maceral distribution in composite coal seams of the study area (B: Bolu, S: Seben, K: Kıbrıscık, Ç: Çamlıdere).

approximately lignite to high volatile "C" bituminous (figure 4), as per German (DIN) and North American (ASTM) classifications.

In some samples, calorific values, volatile-matter contents, elemental carbon and Rm coincide in this slightly higher rank coal, such as in the Kibriscik lignites. This higher degree of maturation is probably attributable to more extensive tuff deposition and lava interlayers in these particular regions, as compared to the other coal fields.

Maceral distributions of the composite samples are given in table 3 . As seen in this table and in figure 5 , the lignite samples are characterised by high huminite contents, mainly gelinite macerals. The lignites do not exhibit cellular structures but are mostly gelified forms of humunite. Contents of liptinite macerals (mainly sporinite and cutinite) are slightly higher than the inertinite macerals (mainly macrinite). The lignite is also characterised by a high mineral-matter content, mainly clay minerals, quartz, calcite and pyrite.

The tissue preservation index (TPI) and gelification index (GI) were calculated according to the methodology of Toprak (1996). Figure 6 gives a TPI/GI cross-correlation plot. These results indicate a limnic depositional environment for the studied lignite.

\subsection{Mineralogy}

\subsubsection{Bolu coal fields}

The mineral matter of the Düvenlik and Çaygökpinar coal samples comprises mainly clay minerals (illite-smectite and kaolinite), plagioclase and opal CT (table 4).

\subsubsection{Seben coal fields}

The mineral composition of the Hoças coal samples consists mainly of clay minerals (illite-smectite,

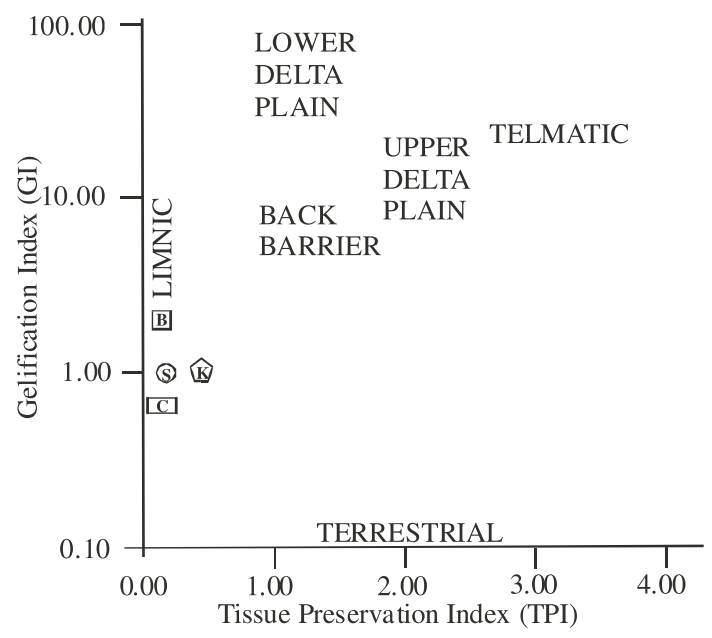

Figure 6. Facies diagram (TPI vs. GI) and suggested depositional environments for the studied coals (B: Bolu, S: Seben, K: Kıbrıscık, Ç: Çamlıdere) modified from Toprak (1996).

smectite, illite), quartz, calcite, plagioclase and, locally, gypsum. The Kassbiyıklar coal samples contain clay minerals (illite-smectite, smectite, illite), calcite, plagioclase and quartz, whereas in samples K-2 and K-3, K-feldspar is present and in sample K-2 opal CT and clinoptilolite occur (table 4).

\subsubsection{Kıbrıscık coal fields}

The mineral matter of Kibriscik coal samples comprises mainly quartz, K-feldspar, plagioclase and clay minerals (kaolinite, illite). In addition to these minerals, analcime (in Ka-4 and Ka-6), gypsum (in $\mathrm{Ka}-5$ ), and dolomite (in Ka-1 and $\mathrm{Ka}-6$ ) were identified (table 4).

\subsection{4 Çamludere coal fields}

The Çamlıdere coal samples contain dolomite, quartz, clinoptilolite, opal CT and gypsum (table 4).

Bearing in mind the ash and mineral-matter contents of the studied samples, two different lignites can be distinguished: (i) the Kibriscik and Camlıdere lignites, which are characterised by high-medium ash contents $(38-58 \%)$ and relatively high proportions of detrital minerals, which were derived from explosive volcanic events; (ii) the other lignites, which have relatively high proportions of clay minerals with variable ash contents (32-36\%). These two different types of lignite, with different specific mineralogical patterns, may be a result of explosive volcanic events and resultant changing depositional conditions from one coal field to another. There is a general trend of decreasing kaolinite contents from Bolu (NW part 
Table 4. Mineral distributions of coal samples from the investigated area.

\begin{tabular}{|c|c|c|c|c|c|c|c|c|c|c|c|c|c|c|c|c|c|}
\hline \multirow[b]{2}{*}{ Location } & \multirow[b]{2}{*}{ Sample } & \multicolumn{16}{|c|}{$\mathrm{XRD}$} \\
\hline & & I & $\mathrm{S}$ & I-S & K & Q & $\mathrm{C}$ & $\mathrm{P}$ & $\mathrm{F}$ & $\mathrm{Kl}$ & $\mathrm{J}$ & $\mathrm{CT}$ & A & $\mathrm{Pi}$ & $\mathrm{Ar}$ & Do & An \\
\hline Düvenlik & 1 & & & 1 & 2 & & & & & & & 3 & 4 & & & & \\
\hline Düvenlik & 2 & & 1 & & 2 & & & 3 & & & & & & & & & \\
\hline Hoçaş & 1 & & 1 & & & & & 2 & & & & & & & & & \\
\hline Hoçaş & 2 & 2 & & 1 & & 4 & & 5 & & & & 3 & 6 & & & & \\
\hline Hoçaş & 3 & & & 3 & & 4 & 1 & 5 & & & & 2 & & & & & \\
\hline Hoçaş & $4 \mathrm{a}$ & & 3 & 2 & & 5 & 1 & 6 & & & & 4 & & & & & \\
\hline Hoçaş & $4 b$ & & 3 & & & 4 & 2 & 1 & & & 5 & & & 6 & & & \\
\hline Hoçaş & 5 & 2 & 1 & & & 4 & 6 & 3 & & & 5 & & & & & & \\
\hline Kaşbıyıklar & Köm 1 & 6 & & 1 & & 4 & 2 & 5 & 6 & & & 3 & & & & & \\
\hline Kaşbıyıklar & Köm 1a & & 3 & 4 & & & 1 & 2 & & & 5 & & & & & & \\
\hline Kaşbıyıklar & Köm 1b & & 1 & & & 3 & & 2 & & 4 & 5 & & & & & & \\
\hline Kaşbıyıklar & Köm 1c & & 2 & & & & 1 & 3 & & & & & & & & & \\
\hline Kaşbıyıklar & Köm 1d & & 1 & & & & 3 & 2 & & & & 4 & & & & & \\
\hline Kaşbıyıklar & Köm 1e & 4 & 1 & & & & 3 & 2 & & & & & & & & & \\
\hline Kaşbıyıklar & Köm 1f & 5 & 1 & & & & 3 & 2 & & & & & & & 4 & & \\
\hline Kaşbıyıklar & Köm 2 & 5 & & 1 & & & 2 & 3 & 4 & 7 & & 6 & & & & & \\
\hline Kaşbıyıklar & Köm 3 & & & 1 & & 3 & 2 & 4 & 5 & & & & 6 & & & & \\
\hline Kaşbıyıklar & Köm 4 & 4 & & 3 & & 5 & 2 & 1 & & & & & & & & & \\
\hline Kaşbıyıklar & Köm 5 & 3 & 1 & 2 & & 4 & & 5 & & & & & & & & & \\
\hline Kaşbıyıklar & K 1 & & & 1 & & 5 & 3 & 4 & & & & 2 & & & & & \\
\hline Kaşbıyıklar & K 2 & 7 & & 1 & & 3 & 2 & 4 & 7 & 6 & & 5 & & & & & \\
\hline Kaşbıyıklar & K 3 & & & 1 & & 4 & 2 & 5 & 6 & & & & 3 & & & & \\
\hline Kaşbıyıklar & K 4 & 4 & & 3 & & 5 & 2 & 1 & & & & & & & & & \\
\hline Kaşbıyıklar & K 5 & 2 & 1 & & 3 & 4 & & & & & & & & & & & \\
\hline Kabalar & Ka 2 & & & & 4 & 1 & & 3 & 4 & & & & & & & & \\
\hline Kabalar & Ka 3 & 5 & & 4 & 3 & 1 & & & 2 & & & & & & & & \\
\hline Kabalar & Ka 4 & 7 & & 6 & 2 & 1 & & 3 & 4 & & & & & & & & \\
\hline Kabalar & Ka 5 & & & & 5 & 1 & 4 & 2 & 3 & & 6 & & & & & & \\
\hline Kabalar & Ka 6 & 7 & 6 & & 5 & 4 & & & 3 & & & & & & & 2 & 1 \\
\hline Kabalar & Ka 7 & 4 & 1 & & & 3 & & 2 & & & & & & & & & \\
\hline Buğralar & Bu 26 & & & & & 2 & & & & 3 & & 5 & 4 & & & 1 & \\
\hline
\end{tabular}

I: Illite; S: Smectite; I-S: Illite-Smectite; K: Kaolinite; C: Calcite; P: Plagioclase; F: K-Feldspar; J: Gypsum; CT: Opal CT; A: Amorph; Pi: Pyrite; Do: Dolomite; An: Analcime; Q: Quartz; Ar: Aragonite and Kl: Clinoptilolite.

of the region) to Seben ( $\mathrm{S}$ part of the region). Coal deposition in this region was syngenetic with volcanic-ash deposition.

Gypsum in the Seben coal samples indicate a low water table in the environment due to evaporation; thus the depositional environment was quite shallow and the water table was beneath the peatland. Coal samples taken from the southern part of the study area (Kıbrıscık, Seben and Çamlıdere) contain opal CT, clinoptilolite and analcime. Volcanic glass, derived from the Uludere Pyroclastics, was probably the major detrital (mineral matter) component in the precursor peat bogs of the studied coal fields. The presence of different zeolite minerals indicates that there probably were different proportions of $\mathrm{Na}$ and/or $\mathrm{K}$ to $\mathrm{Ca}$, and $\mathrm{Al}$ to $\mathrm{Si}$, in the precursor volcanic ash or in the pore fluids. Analcime crystallization reflects a high $\mathrm{Na}$ : Ca ratio in the activation solution and relatively high $\mathrm{Al}: \mathrm{Si}$ ratio in the volcanic ash, whereas clinoptilolite reflects somewhat lower $\mathrm{Na} / \mathrm{K}: \mathrm{Ca}$ and $\mathrm{Al}: \mathrm{Si}$ ratios (Gündoğdu et al 1996; Temel and Gündoğdu 1996; Whateley et al 1996). From SW to SE in the study area, there is a zonation as follows: opal CT + smectite $\rightarrow$ clinoptilolite $\rightarrow$ analcime $\rightarrow$ K-feldspar. Carbonate minerals are relatively abundant in the coals of the Seben and Kibriscik fields, whereas the Bolu coal samples lack calcite and dolomite. From 
NW to $\mathrm{S}$ in the study area, there is increasing $\mathrm{Mg}$ and decreasing $\mathrm{Na}$. In particular, the Çamlıdere coal samples have higher dolomite contents than do samples from the other coal fields; thus its depositional environment was probably relatively deeper than the others.

\section{Conclusions}

The coal-bearing Hirka Formation in NW central Anatolia formed under initially favourable, warm, humid, tropical-subtropical palaeoclimatic conditions which later evolved into slightly drier and cooler conditions. The main features of these lignites resulted from the tectonic evolution and volcanic features of the basin due to the influence of tectonics and volcanism on the sedimentation and subsidence rates and on basin morphology.

According to previous research on the geochemical conditions of the Mesozoic and Tertiary coal deposits of the Mediterranean region, all coal seams were deposited in alkaline environments, with high bacterial activity and high organic sulphur contents (Querol et al 1999). Not only the geochemical features but also the mineralogical and sedimentological features show that volcanic activity had a major influence on fossil-fuel deposition (namely, coal and oil shale) especially in Turkey during the Neogene epoch and/or neotectonic period.

A key result of this study of the Hirka Formation is recognition of the major influence exerted on the early diagenetic evolution of the coal by explosive volcanic events proximal to the lacustrine environments and has very different properties than the other coal fields of Turkey (figure 5). To date, the thick pyroclastic cover in the $\sim 1100 \mathrm{~km}^{2}$ study area has had a profoundly negative effect on coal exploration. However, exploratory drilling - guided by the results of the present study - may lead to the discovery of major new coal deposits.

\section{Acknowledgements}

This study was supported by MTA (General Directorate of Mineral Research and Exploration of Turkey). I would like to express my appreciation to the staff of the Energy Department of MTA for their invaluable work on this project. I am also grateful to M Taka, A İ Gevrek, İ Şengüler and A Temel for comments and valuable discussions on the manuscript. Many thanks are also due to Santanu Banerjee and Mehmet Keskin for comments on the manuscript.

\section{References}

Aziz A 1976 Beypazarı, Yeni Çayırhan ve Karaköy arasındaki sahanı jeolojisi ve bitümlü şist olanakları; MTA Raporu Derleme No. 5732.

Blumenthal M 1941 Bolu civarı ile Aağı Kızılırmak mecrası arasındaki Kuzey Anadolu silsilelerinin jeolojisi; MTA Seri B, No: 13.

Chaput E 1931 Notice explicative de la carte geologique au 1/135.000 de la region d'Ankara; Bull. Fac. Sc. Univ. Istanbul 7(3) 1-46.

Güleç N 1991 Crust-mantle interaction in western Turkey: implications from $\mathrm{Sr}$ and isotope geochemistry of Tertiary and Quaternary volcanics; Geological Magazine $\mathbf{1 2 8}$ $417-435$.

Gündoğdu M N, Yalçın H, Temel A and Clauer N 1996 Geological, mineralogical and geochemical characteristics of zeolite deposits associated with borates in the Bigadiç, Emet and Kırka Neogene lacustrine basins, western Turkey; Mineralium Deposita 31 492-514.

Inci U 1991 Miocene alluvial fan-alkaline playa lignite-trona bearing deposits from an inverted basin in Anatolia: sedimentology and tectonic controls on deposition; Sedim. Geol. 71 73-97.

Milch L 1903 Die Ergussgesteine des Galatischen Andesitgebietes; Neues Jahrbuch für Mineralogie $\mathbf{1 6}$ $110-165$.

Querol X, Alastuer A, Plana F, Lopez-Soler A, Tuncalı E, Toprak S, Ocakoğlu F and Koker A 1999 Coal geology and coal quality of the Miocene Muğla basin; Int. J. Coal Geol. 41 311-332.

Şener M, Sengüler I and Kök M V 1995 Geological considerations for the economic evaluation of oil shale deposits in Turkey; Fuel 74 999-1003.

Şener M and Gündoğdu M N 1996 Geochemical and petrographic investigation of Himmetoğlu oil shale field, Göynük, Turkey; Fuel 75 1313-1322.

Şengör A M C 1980 Türkiye'nin neotektoniğinin esasları; TJK Publ.

Şengör A M C and Yılmaz Y 1981 Tethyan evolution of Turkey: a plate tectonic approach; Tectonophys. $\mathbf{7 5}$ $181-241$.

Şengör A M C, Görür N and Şaroğlu F 1985 Strike-slip faulting and related basin formation in zones of tectonic escape: Turkey a case study; In: Strike-slip Deformation, Basin Formation, and Sedimentation, (eds) K T Biddle and N Christie-Blick; Soc. Econ. Paleont. Min. Spec. Publ. (in honor of J C Crowell) 37 227-264.

Şengüler I, Şener M, Kök M V 2000 Paleotemperature Analysis of Aliağa (İzmir, Turkey) Geothermal Field; Energy Sources 22(4) 357-363.

Taka M, Şener M and Gevrek A İ 2001 Seben-GeredeKıbrıscık (Bolu)-Beypazarı Çamlıdere-Güvem (Ankara) alanında yüzeylenen Üst Miyosen volkanitleri altındaki birimlerin enerji hammadde potansiyeli; MTA Raporu No. 10214.

Temel A and Gündoğdu M N 1996 Zeolite occurrences and the erionite-mesothelioma relationship in Cappadocia, central Anatolia, Turkey; Mineralium Deposita 31 $539-518$.

Toprak S 1996 Determination of depositional environments and properties of coals located in the vicinity of Alpagut-Dodurga (Osmancık-Çorum) region; Ph.D. thesis, Hacettepe University, Ankara, Turkey (in Turkish).

Türkecan A, Hepşen N, Papak İ, Akbaş B, Dinçel A, Karataş S, Özgür İ B, Akay E, Bedi Y, Sevin M, Mutlu G, Sevin D, Ünay E and Saraç G 1991 
Seben-Gerede (Bolu), Güdül-Beypazarı (Ankara) ve Çerkeş- Orta-Kurunlu (Çankırı) yörelerinin jeolojisi ve volkanik kayaçlarm petrolojisi; MTA Raporu Derleme No. 9193.

Yılmaz Y 1989 An approach to the origin of young volcanic rocks of western Turkey; In: Tectonic evolution of the Tethyan region (ed.) Şengör A M C (Hague: Kluwer) $159-189$.
Whateley M K G and Tuncalı E 1995 Quality variations in the high sulphur lignite of the Neogene Beypazarı basin, central Anatolia, Turkey; International Journal of Coal Geology 27 131-151.

Whateley M K G, Querol X, Fernandez-Turiel J L and Tuncalı E 1996 Zeolites in Tertiary coal from the Çayırhan mine, Beypazarı, Turkey; Mineralium Deposita $\mathbf{3 1}$ 529-538.

MS received 4 September 2006; revised 9 October 2006; accepted 18 October 2006 